\title{
The Superiority of T2*MRI Over Serum Ferritin in the Evaluation of Secondary Iron Overload in a Chronic Kidney Disease Patient: A Case Report
}

\author{
Abdulrahman \\ Al-Mashdali (iD) \\ Tahiya Alyafei \\ Mohamed Yassin (iD ${ }^{3}$ \\ 'Department of Internal Medicine, \\ Hamad Medical Corporation, Doha, \\ Qatar; ${ }^{2}$ Department of Clinical Imaging, \\ Hamad Medical Corporation, Doha, \\ Qatar; ${ }^{3}$ National Center for Cancer Care \\ and Research, Department of Oncology, \\ Hematology and BMT Section, Hamad \\ Medical Corporation, Doha, Qatar
}

\begin{abstract}
Secondary iron overload is increasingly encountered in chronic kidney disease (CKD) patients because of the frequent use of parenteral iron products, especially in hemodialysis patients. Serum ferritin has been commonly used to monitor iron overload in these patients; however, other conditions can be associated with the high serum ferritin, like infections and inflammatory conditions. Currently, T2*MRI of the heart and liver is the preferred investigation for evaluating liver iron concentration (LIC) and cardiac iron concentration, which reflect the state of iron overload. Few studies observe a positive correlation between serum iron and LIC in CKD patients and postulate that serum ferritin exceeding 290 $\mathrm{mcg} / \mathrm{L}$ should indicate significant iron overload and necessitates further MRI evaluation. However, here, we present a patient with a history of ESRD for which she underwent renal transplantation twice referred to our clinic due to persistent elevation in serum ferritin level $(>1000 \mathrm{mcg} / \mathrm{L})$ for several years. T2*MRI of the heart and liver revealed the absence of iron overload. Our objective of this case is to demonstrate the accuracy of T2*MRI over serum ferritin in evaluating iron overload and questioning the positive correlation between serum ferritin and LIC in CKD patients.
\end{abstract}

Keywords: secondary iron overload, chronic kidney disease, serum ferritin, T2*MRI, liver iron concentration

\section{Introduction}

Our body normally contains up to 4 grams of iron, mainly in hemoglobin. ${ }^{1}$ The liver is considered the main storage site for iron in the body. Total body iron content is established by balancing iron intake from diet or other sources like blood transfusion and iron loss, such as from menstrual bleeding or epithelial cells shedding. ${ }^{2}$ However, no physiological mechanism for the excretion of excess iron has been found in the human body. ${ }^{3}$ Iron overload occurs either due to the excess of iron intake, which exceeds its loss from the body, like thalassemia and sickle cell disease patients requiring chronic blood transfusion ${ }^{4,5}$ or due to the increase in iron absorption from the gut despite normal intake, such in hereditary hemochromatosis. ${ }^{6}$ Less frequently, iron overload can happen due to iatrogenic intoxication. ${ }^{7}$

In general, secondary iron overload in ESRD patients is uncommon; however, iron overload has been increasingly diagnosed in the ESRD population over the last decade for multiple reasons. First, given the risk of iron deficiency with erythropoiesis-stimulating agents (ESA) therapy, KDIGO 2012 guideline set $500 \mu \mathrm{g} / \mathrm{L}$ as the upper limit of serum ferritin in ESRD patients on hemodialysis, which encouraged
Correspondence: Abdulrahman Al-Mashdali Department of Internal Medicine, Hamad Medical Corporation (HMC), P.O. Box 3050, Al Rayyan Road, Doha, Qatar Tel +96750700816

Email AAlmashdali@hamad.qa 
the clinicians to give more intravenous iron to prevent iron deficiency in such patients. Moreover, the recent advance in the diagnostic test for iron overload (particularly MRI) plays a significant role in the early detection of more iron overload cases. $^{8,9}$

Because of their availability and lower cost, serum ferritin and transferrin saturation (TSAT) are frequently used to monitor iron accumulation in the body. Though, these parameters can be affected by different conditions, especially infections and variable inflammatory conditions. However, the evidence for the correlation between serum ferritin with liver iron concentration (LIC) and heart iron concentration is still not well established in patients with chronic kidney disease suspected to have iron overload. ${ }^{10}$

Here, we present a patient with a history of end-stage renal disease (ESRD) and renal transplants referred to our clinic because of persistently elevated serum ferritin for several years. T2* MRI of the heart and liver revealed no evidence of iron overload. In this case, we highlight the superiority of $\mathrm{T} 2 *$ MRI of the heart and liver over serum ferritin in evaluating iron overload in CKD patients.

\section{Case Presentation}

A 57-year-old female who referred to our hematology clinic due to persistent elevation in her serum ferritin. Her past medical history was significant for end-stage renal disease (ESRD) due to diabetic nephropathy, for which she underwent kidney transplantation on two occasions. The first kidney transplant was done in 2002 (then, her kidney functions were stable from 2002 until 2016, when they started to deteriorate due to recurrent diabetic nephropathy in the transplanted kidney leading to chronic allograft dysfunction, which required hemodialysis thrice weekly for six months before the second transplant), and the second one in 2017 (Both kidneys transplants were donated voluntarily, the first one from patient's relative and the second from family's friend, with written informed consent, and the organ donation was conducted in accordance with the declaration of Istanbul). The patient also had a past medical history of hypertension and breast cancer diagnosed in 2006 treated with a combination of lumpectomy, chemotherapy, and radiotherapy.

At her initial visit to our clinic, the patient denied any symptoms related to iron overload complications. Her vital signs were within the normal limit. Her body mass index (BMI) was 27. Laboratory findings were significant for serum ferritin of $1219.0 \mu \mathrm{g} / \mathrm{L}$ (normal level < 300), serum iron of $14 \mu \mathrm{mol} / \mathrm{L}$ (normal 9-30), TIBC of 50 $\mu \mathrm{mol} / \mathrm{L}$ (normal $40-80$ ), iron saturation of $38 \%$ (normal 15-45\%). Her liver function tests are normal. Also, Her $\mathrm{HbA} 1 \mathrm{C}$ levels were between $7 \%$ and $8 \%$ for the last five years. Of note, her serum ferritin was repeatedly exceeding $1000 \mu \mathrm{g} / \mathrm{L}$ for the last five years (her renal functions, serum ferritin, TSAT were near normal from 2002 until 2016). Our patient did not have any chronic infection, inflammatory condition, liver disease, or active malignancy (she was asymptomatic with normal inflammatory markers) that could lead to elevated ferritin levels over the last five years. The patient denied smoking or alcohol drinking. We summarized the relevant data from 2016 to 2021 in Table 1.

Given her past medical history of ESRD requiring hemodialysis, secondary iron overload was suspected. Accordingly, an T2*MRI of the heart and liver was suggested to rule out iron deposition in body organs. MRI heart revealed iron deposition of less than $1.2 \mathrm{mg} / \mathrm{g}$ of dry heart weight. The MRI liver showed an iron deposition of less than $5 \mathrm{mg} / \mathrm{g}$ of dry liver weight, consistent with the absence of myocardial and hepatic iron overload (Figures 1 and 2). Table 2 shows the severity classification of iron overload (both for liver and heart) based on T2*MRI findings. Accordingly, the patient was reassured and treated conservatively. In most recent follow-up in our clinic, the patient was doing fine and asymptomatic, and her latest serum ferritin was $940 \mu \mathrm{g} / \mathrm{L}$.

\section{Discussion}

Iron overload is classified into primary and secondary iron overload. The most common cause of the primary iron overload is hereditary hemochromatosis. The secondary iron overload might occur in the context of different hematological disorders, mainly hemoglobinopathies and CKD. Different mechanisms can lead to iron accumulation associated with hematological diseases, including longterm blood transfusion, chronic hemolysis, increased intestinal absorption of iron due to ineffective hematopoiesis, or genetic mutation in hepcidin. ${ }^{11,12}$ Iron overload with CKD may happen due to frequent intravenous iron use, especially in patients on hemodialysis. However, the risk of iron toxicity in ESRD patients is usually insignificant because other factors minimize iron accumulation, including the concurrent use of erythropoiesis-stimulating agents (ESA) and the distribution of hepatic iron by the reticuloendothelial cells. ${ }^{13}$ However, as mentioned in the introduction, iron overload is increasingly discovered in hemodialysis patients since that the majority of ESRD 
Table I Summary of Relevant Data from 2016 to 2021 (Since the Detection of the Elevated Serum Ferritin)

\begin{tabular}{|c|c|c|c|c|c|c|c|}
\hline Data & Reference Value & $\begin{array}{l}2016 \text { (HD Initiated by } \\
\text { the End of This Year) }\end{array}$ & 2017(Before Renal Tx) & $\begin{array}{l}2018 \\
\text { (After } \\
\text { Renal Tx) }\end{array}$ & 2019 & 2020 & $\begin{array}{l}\text { 202I (When } \\
\text { T2*MRI } \\
\text { Done) }\end{array}$ \\
\hline Hb level (range) & $12-15 \mathrm{gm} / \mathrm{dL}$ & $10.2-11$ & $8.8-10.4$ & $11.6-12.2$ & $11.3-11.8$ & $10.9-11.4$ & $12.2-12.9$ \\
\hline WBC & $4-10 \times 10^{\wedge} 3 / u L$ & 7.3 & 6.5 & 3.9 & 4.6 & 6.2 & 5.5 \\
\hline Serum ferritin & $<300 \mathrm{mcg} / \mathrm{L}$ & 282 & 1150 & 1830 & 1650 & 1933 & 1219 \\
\hline TSAT & $15-45 \%$ & 39 & 49 & 52 & 46 & 48 & 38 \\
\hline Creatinine(range) & $50-95 \mathrm{umol} / \mathrm{L}$ & $168-205$ & $\begin{array}{l}\text { 320-380 (required HD } 3 \\
\text { times /week) }\end{array}$ & $75-118$ & $105-115$ & $100-120$ & $105-123$ \\
\hline Iron received & Total & None & $\begin{array}{l}\text { Intravenous ferrous } \\
\text { carboxymaltose (>3 gm over } 6 \\
\text { months) }\end{array}$ & None & None & None & None \\
\hline Blood transfusion & Units/year & None & $\begin{array}{l}\text { Two units of PRBC before renal } \\
\text { Tx }\end{array}$ & None & None & None & None \\
\hline ESA & Weekly & None & $\begin{array}{l}\text { Received darbepoetin for six } \\
\text { months before renal } T x\end{array}$ & None & None & None & None \\
\hline CRP level & $<6 \mathrm{mg} / \mathrm{L}$ & 4 & 11.4 & 6.4 & 4.2 & 3.8 & 2.1 \\
\hline
\end{tabular}

Abbreviations: CRP, C-reactive protein; Hb, hemoglobin; HD, hemodialysis; TSAT, transferrin saturation; TX, transplantation; WBC, white blood cells.

patients treated with ESA receive parenteral iron to replenish iron storage and ensure iron availability for hematopoiesis. ${ }^{8}$

Iron overload mainly affects the parenchymal cells of the liver, heart, and endocrine organs. Iron accumulation leads to tissue inflammation and damage through the formation of reactive oxygen species. ${ }^{14}$ As the main store for iron in the body, the liver is the most affected organ by iron overload. Different manifestations may result from excessive iron deposition in the liver, ranging from elevated liver enzymes to liver cirrhosis. Indeed, liver cirrhosis is rarely encountered in hemodialysis patients who developed iron overload. ${ }^{15,16}$ Iron deposition in the myocardial tissue can occasionally lead to cardiomyopathy. ${ }^{17}$ Also, iron overload might increase atherosclerosis risk in ESRD patients. ${ }^{18}$ In addition to its effects on different

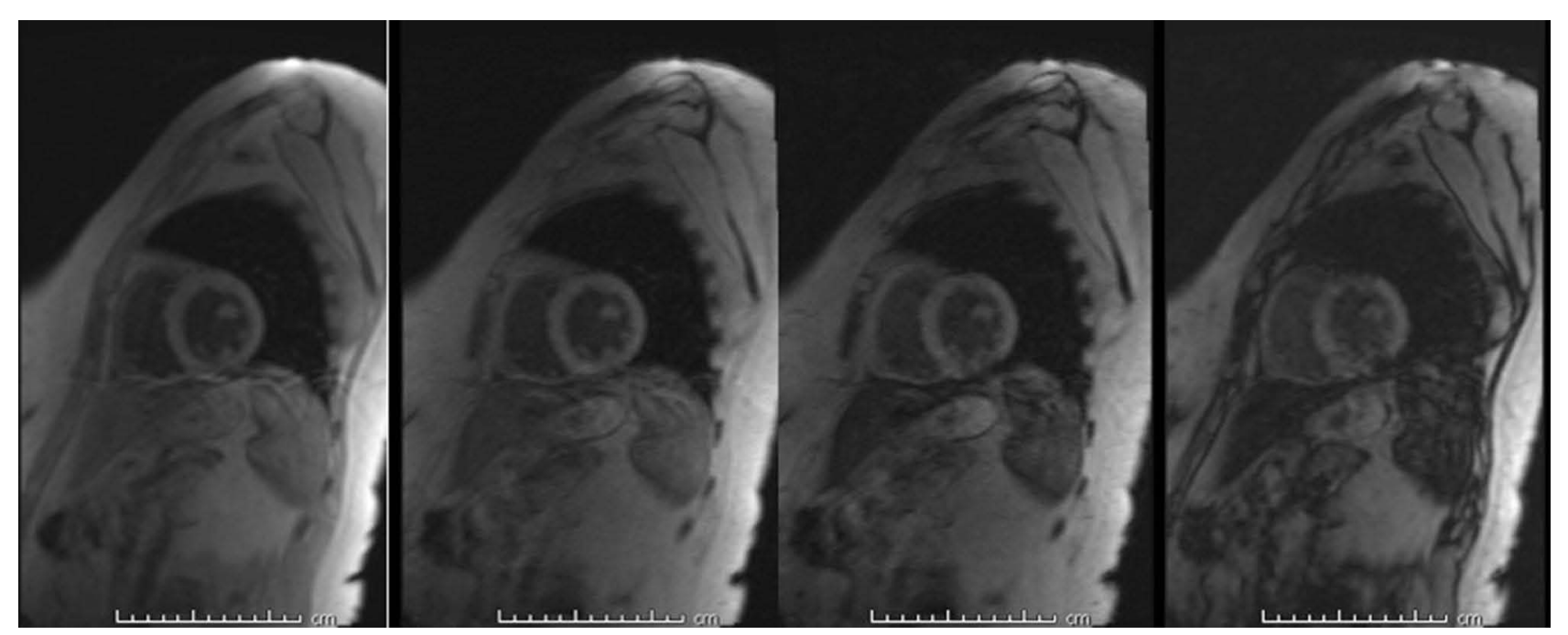

Figure I MRI I.5 T (Siemens Avanto), using multi-TE gradient echo T2* MRI technique. Heart intensity is normal seen with the longest TE (I4.68 msec). T2* =29.4 ms corresponding to $<1.2 \mathrm{mg}$ Iron/g heart dry weight. 


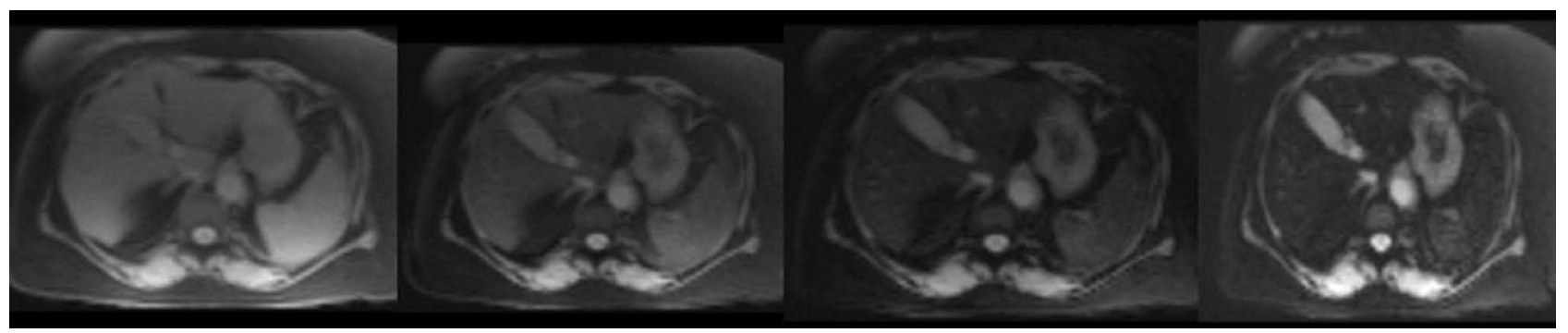

Figure 2 MRI I.5 T (Siemens Avanto), using multi-TE gradient echo T2* MRI technique (using Garbowski method). Liver intensity is normal seen with the longest TE (I4.68 $\mathrm{msec})$. $\mathrm{T} 2^{*}=7.4 \mathrm{~ms}$, corresponding to $<5 \mathrm{mg}$ Iron/ g liver dry weight.

organs, iron overload may increase the risk of infection by disturbing the functions of different immune cells and, as an essential element, by enhancing bacterial growth and multiplication. $^{16}$

Liver iron concentration (LIC) provides a precise representation of body iron storage in patients with iron overload. ${ }^{19}$ At present, MRI becomes the modality of choice for the assessment of iron overload. ${ }^{20}$ The sensitivity and specificity of standardized MRI protocol in determining LIC are estimated to be $94 \%$ and $100 \%$, respectively. $^{21}$ The role of MRI methods for evaluating iron overload is well recognized in transfusion-dependent anemia patients; however, this role is still not well established in ESRD patients. ${ }^{12,16}$ Given the very high sensitivity (resulting in the low false-negative result) of T2*MRI in the diagnosis of iron overload, we excluded secondary iron overload in our patient, especially in the absence of any clinical or laboratory evidence for that. Few studies were evaluated the correlation between serum ferritin and LIC in CKD patients on hemodialysis by using various MRI standardized protocols. A study done by Canavese et al assumed that the risk of iron overload is ten times more in CKD patients with serum ferritin value surpasses $500 \mathrm{mcg} / \mathrm{L}^{22}$ Another study concluded that there is no correlation between serum iron markers and LIC in CKD patients. ${ }^{23}$ The latest studies of the correlation between serum ferritin and LIC in hemodialysis patients using $\mathrm{T} 2 * \mathrm{MRI}$ found a positive correlation between these two variables. Therefore, it was suggested that serum ferritin value above $290 \mathrm{mcg} / \mathrm{L}$ should justify further investigation with MRI to rule out iron overload in such cases. ${ }^{24,25}$ Though different observation was reported in one EDRD patient with a serum ferritin level of $>1000$ $\mathrm{mcg} / \mathrm{L}$, his LIC measured by $\mathrm{T} 2 * \mathrm{MRI}$ was suggestive of only mild iron accumulation liver. ${ }^{12}$ In our case, we also observed that despite the serum ferritin was $>1000 \mathrm{mcg} / \mathrm{L}$ for several years, the T2*MRI of the heart and liver showed no evidence of iron overload. Our finding could support the idea that serum ferritin might not correlate with LIC and cardiac iron concentration in ESRD patients.

\section{Conclusion}

Despite that, the existing guidelines recommend serum ferritin and transferrin saturation for monitoring secondary iron overload in CKD patients; the evidence for the correlation between serum ferritin and LIC measured by MRI is still scarce in CKD patients. Few studies observe a positive correlation between serum iron and LIC in CKD patients and postulate that serum ferritin above 290 $\mathrm{mcg} / \mathrm{L}$ should indicate significant iron overload and necessitates MRI evaluation. However, our patient had a serum ferritin level of $>1000 \mathrm{mcg} / \mathrm{L}$ for several years, but a T2*MRI of the heart and liver revealed the absence of iron overload. We think that further studies are necessary to prove this correlation and determine the cutoff level of serum ferritin that requires further evaluation of iron overload by MRI in CKD patients.

Table 2 Severity of Iron Overload Based on Hepatic and Myocardial T2*MRI and Our Patient Findings

\begin{tabular}{|c|c|c|c|c|c|}
\hline Iron Load Severity & Normal & Mild & Moderate & Severe & Our Patient \\
\hline $\begin{array}{l}\text { Hepatic T2* by millisecond(ms), mg } \\
\text { iron/ } g \text { of liver dry weight }\end{array}$ & $\begin{array}{l}>7.2 \mathrm{~ms},< \\
5 \mathrm{mg} / \mathrm{g}\end{array}$ & $\begin{array}{l}3.3-7.2 \mathrm{~ms} \\
5-10 \mathrm{mg} / \mathrm{g}\end{array}$ & $\begin{array}{l}2.2-3.3 \mathrm{~ms} \\
10-15 \mathrm{mg} / \mathrm{g}\end{array}$ & $\begin{array}{l}<2.2 \mathrm{~ms} \\
>15 \mathrm{mg} / \mathrm{g}\end{array}$ & $\begin{array}{l}\mathrm{T} 2 *=7.4 \mathrm{~ms} \text {, corresponding to }<5 \mathrm{mg} \text { iron/ } \\
\mathrm{g} \text { of liver dry weight (Normal) }\end{array}$ \\
\hline $\begin{array}{l}\text { Myocardial T2*by millisecond(ms), mg } \\
\text { iron/ } g \text { of heart dry weight }\end{array}$ & $\begin{array}{l}>20 \mathrm{~ms} \\
<1.2 \mathrm{mg} / \mathrm{g}\end{array}$ & $\begin{array}{l}\mathrm{I} 4-20 \mathrm{~ms} \\
\mathrm{I} .2-1.8 \mathrm{mg} / \mathrm{g}\end{array}$ & $\begin{array}{l}10-14 \mathrm{~ms} \\
1.8-2.7 \mathrm{mg} / \mathrm{g}\end{array}$ & $\begin{array}{l}<10 \mathrm{~ms} \\
>2.7 \mathrm{mg} / \mathrm{g}\end{array}$ & $\begin{array}{l}\mathrm{T} 2 *=29.4 \mathrm{~ms} \text {, corresponding to }<1.2 \mathrm{mg} \text { iron/ } \\
\mathrm{g} \text { of heart dry weight (Normal) }\end{array}$ \\
\hline
\end{tabular}




\section{Consent}

Written informed consent was obtained from the patient for the publication of this case report. This case report was approved by the Hamad Medical Corporation's Medical Research Center (Protocol number: MRC-04-21-419).

\section{Acknowledgments}

The authors would like to acknowledge Qatar National Library (QNL) for this publication's funding and the HMC internal medicine residency program for scientific support.

\section{Disclosure}

The authors report no conflicts of interest in this work.

\section{References}

1. Cook JD, Flowers CH, Skikne BS. The quantitative assessment of body iron. Blood. 2003;101(9):3359-3364. Epub 2003 Jan 9. PMID: 12521995. doi:10.1182/blood-2002-10-3071

2. McLaren GD, Muir WA, Kellermeyer RW. Iron overload disorders: natural history, pathogenesis, diagnosis, and therapy. Crit Rev Clin Lab Sci. 1983;19(3):205-266. PMID: 6373141. doi:10.3109/ 10408368309165764

3. Siddique A, Kowdley KV. Review article: the iron overload syndromes. Aliment Pharmacol Ther. 2012;35(8):876-893. Epub 2012 Mar 4. PMID: 22385471. doi:10.1111/j.1365-2036.20 12.05051.x

4. Khan AM, Al-Sulaiti AM, Younes S, Yassin M, Zayed H. The spectrum of beta-thalassemia mutations in the 22 Arab countries: a systematic review. Expert Rev Hematol. 2021;14(1):109-122. Epub 2020 Dec 29. PMID: 33317346. doi:10.1080/1747408 6.2021 .1860003

5. Yassin M, Soliman A, De Sanctis V, et al. Liver iron content (LIC) in adults with sickle cell disease (SCD): correlation with serum ferritin and liver enzymes concentrations in trasfusion dependent (TD-SCD) and non-transfusion dependent (NT-SCD) patients. Mediterr J Hematol Infect Dis. 2017;9(1):e2017037. PMID: 28698780; PMCID: PMC5499497. doi:10.4084/MJHID.2017.037

6. Cullis JO, Fitzsimons EJ, Griffiths WJ, Tsochatzis E, Thomas DW; British Society for Haematology. Investigation and management of a raised serum ferritin. Br J Haematol. 2018;181(3):331-340. Epub 2018 Apr 19. PMID: 29672840. doi:10.1111/bjh.15166

7. Yassin M, Soliman AT, De Sanctis V, Moustafa A, Samaan SA, Nashwan A. A young adult with unintended acute intravenous iron intoxication treated with oral chelation: the use of liver ferriscan for diagnosing and monitoring tissue iron load. Mediterr $J$ Hematol Infect Dis. 2017;9(1):e2017008. PMID: 28101313; PMCID: PMC5224804. doi:10.4084/MJHID.2017.008

8. Rostoker G, Vaziri ND, Fishbane S. Iatrogenic iron overload in dialysis patients at the beginning of the 21st century. Drugs. 2016;76(7):741-757. PMID: 27091216; PMCID: PMC4848337. doi:10.1007/s40265-016-0569-0

9. Aldwairi MM, Yassin MA. Iatrogenic iron overload in an end stage renal disease patient. Case Rep Oncol. 2020;13(2):760-763. PMID: 32774272; PMCID: PMC7383200. doi:10.1159/000507979

10. Kanbour I, Chandra P, Soliman A, et al. Severe liver iron concentrations (LIC) in 24 patients with $\beta$-thalassemia major: correlations with serum ferritin, liver enzymes and endocrine complications. Mediterr J Hematol Infect Dis. 2018;10(1):e2018062. PMID: 30416694; PMCID: PMC6223579. doi:10.4084/MJHID.2018.062
11. Yassin MA, Soliman A, De Sanctis V, et al. The impact of iron overload in patients with acute leukemia and myelodysplastic syndrome on hepatic and endocrine functions. Acta Biomed. 2018;89(3S):18-22. PMID: 29633728; PMCID: PMC6179097. doi:10.23750/ abm.v89i3-S.7213

12. Ali M, Okar L, Iqbal P, Yassin MA. Iatrogenic iron overload in a patient with chronic kidney disease: is there a correlation between serum ferritin and liver iron concentration determined by MRI T2*? Cureus. 2020;12(6):e8914. PMID: 32742880; PMCID: PMC7389957. doi:10.7759/cureus.8914

13. Wish JB, Aronoff GR, Bacon BR, et al. Positive iron balance in chronic kidney disease: how much is too much and how to tell? $\mathrm{Am}$ J Nephrol. 2018;47(2):72-83. Epub 2018 Feb 13. PMID: 29439253. doi: $10.1159 / 000486968$

14. Le Lan C, Loréal $\mathrm{O}$, Cohen $\mathrm{T}$, et al. Redox active plasma iron in C282Y/C282Y hemochromatosis. Blood. 2005;105(11):4527-4531. Epub 2005 Jan 25. PMID: 15671444. doi:10.1182/blood-2004-09-3468

15. Soliman A, Yassin M, Al Yafei F, et al. Longitudinal study on liver functions in patients with thalassemia major before and after deferasirox (DFX) therapy. Mediterr J Hematol Infect Dis. 2014;6(1): e2014025. PMID: 24803998; PMCID: PMC4010606. doi:10.4084/ MJHID.2014.025

16. Rostoker G, Vaziri ND. Iatrogenic iron overload and its potential consequences in patients on hemodialysis. Presse Med. 2017;46(12 Pt 2):e312-e328. Epub 2017 Nov 16. PMID: 29153377. doi:10.1016/ j.lpm.2017.10.014

17. Gaenzer H, Marschang P, Sturm W, et al. Association between increased iron stores and impaired endothelial function in patients with hereditary hemochromatosis. J Am Coll Cardiol. 2002;40 (12):2189-2194. PMID: 12505233. doi:10.1016/s0735-1097(02) 02611-6

18. Reis KA, Guz G, Ozdemir H, et al. Intravenous iron therapy as a possible risk factor for atherosclerosis in end-stage renal disease. Int Heart J. 2005;46(2):255-264. PMID: 15876809. doi:10.1536/ ihj. 46.255

19. Angelucci E, Brittenham GM, McLaren CE, et al. Hepatic iron concentration and total body iron stores in thalassemia major. $N$ Engl J Med. 2000;343(5):327-331. Erratum in: N Engl J Med 2000 Dec 7;343(23):1740.PMID: 10922422. doi:10.1056/ NEJM200008033430503

20. Fischer R, Harmatz PR. Non-invasive assessment of tissue iron overload. Hematology Am Soc Hematol Educ Program. 2009:2009:215-221. PMID: 20008201. doi:10.1182/asheducation2009.1.215

21. Lyle L, Hirose A. Iron overload in myelodysplastic syndromes: pathophysiology, consequences, diagnosis, and treatment. $J A d v$ Pract Oncol. 2018;9(4):392-405. Epub 2018 May 1. PMID: 30719392; PMCID: PMC6347085.

22. Canavese C, Bergamo D, Ciccone G, et al. Validation of serum ferritin values by magnetic susceptometry in predicting iron overload in dialysis patients. Kidney Int. 2004;65(3):1091-1098. PMID: 14871430. doi:10.1111/j.1523-1755.2004.00480.x

23. Ferrari P, Kulkarni H, Dheda S, et al. Serum iron markers are inadequate for guiding iron repletion in chronic kidney disease. Clin J Am Soc Nephrol. 2011;6(1):77-83. Epub 2010 Sep 28. PMID: 20876673; PMCID: PMC3022252. doi:10.2215/ CJN.04190510

24. Ghoti H, Rachmilewitz EA, Simon-Lopez R, et al. Evidence for tissue iron overload in long-term hemodialysis patients and the impact of withdrawing parenteral iron. Eur J Haematol. 2012;89 (1):87-93. Epub 2012 May 18. PMID: 22435497. doi:10.1111/ j.1600-0609.2012.01783.x

25. Rostoker G, Griuncelli M, Loridon C, et al. Reassessment of iron biomarkers for prediction of dialysis iron overload: an MRI Study. PLoS One. 2015;10(7):e0132006. PMID: 26182077; PMCID: PMC4504469. doi:10.1371/journal.pone.0132006 


\section{Publish your work in this journal}

The Journal of Blood Medicine is an international, peer-reviewed, open access, online journal publishing laboratory, experimental and clinical aspects of all aspect pertaining to blood based medicine including but not limited to: Transfusion Medicine; Blood collection, Donor issues, Transmittable diseases, and Blood banking logistics; Immunohematology; Artificial and alternative blood based therapeutics; Hematology; Biotechnology/nanotechnology of blood related medicine; Legal aspects of blood medicine; Historical perspectives. The manuscript management system is completely online and includes a very quick and fair peer-review system. Visit http://www.dovepress.com/testimonials.php to read real quotes from published authors. 